\title{
INTERNATIONAL LEGAL FRAMEWORK FOR MEDIA
}

\author{
Nevenka Ronkova, master`s student \\ at the Faculty of Law at University "Goce Delchev"-Stip, Macedonia, \\ e-mail: nronkova@yahoo.com;
}

\begin{abstract}
The analysis of the international legal framework for media in a real structural form is a challenge that needs to be scientifically proven because of the exceptional role of media in general and its constant and substantial impact on the democratic processes taking place in the world. If we analyze media through the eyes of history, we cannot ignore the impression of the exceptional importance of freedom of expression as the source and promoter of many substantive changes and valuable components in the overall functioning of social and political settings.

In this regard, special attention is given to the impact of media on contemporary trends related to the EU integration process, the development of democracy and the rule of law. It particularly emphasizes the freedom of expression, respect for values and standards principles, human rights and freedoms.

The purpose of this paper is to analyze the international legal framework for the media and to show the determination of the most important covenants which represent a source of media law containing rules for the creation and implementation of media freedom, the expressive quality of ideas and definitely and inevitably this paper stresses the power of the media.
\end{abstract}

Key words: pact; declaration; convention; media law; freedom of expression.

\section{Introduction}

Nowadays, the media are in fact our lives, having in mind that all day long we are in contact with different types of media (mobile phones, posters, billboards, magazines, televisions, computers, letters). Whether in a conscious way or not, every day through various types of media we receive messages and additional information. Mass communication as a concept, which was defined during the 19th century, is associated with the media. Technology development and the new needs of society make it possible to create new media. Because media has become an irreplaceable part of the everyday life of the modern man, furthermore they have an impact on the development of attitudes, opinions and behaviors there is a need for media studying. Media literacy aims to understand the role and function that media have in the society, but also to develop basic research skills and appropriate expression of the citizens in the democratic society.

We can say that the media represent a mediator or means - channel which provides circulation of information. With the word media are covered a number of modern means of communication, such as: the $\mathrm{TV}$, radio, newspapers, internet, mobile phones, cinemas and so on. Media content denotes symbols, images, text, etc, which are subject of transferring through the media.

\section{Definition of Media}

The term media is the most often used word in modern communication. Regarding the definition of media there are certain difficulties since it has multiple meanings. According to the encyclopedic literature, the term medium is any means of communication through which you can convey a message or information from the communicator to the recipient, regardless of whether the role of communicators or recipients are individuals or groups. So we can say that any asset that provides the mediation of message to be transmitted through time and space, from the source to the recipients is a medium for communication.

Furthermore, the notion of mass media (mass medium) is a means of mass communication which accomplishes diffusion of the message or information from the source to the uncountable mass of 
recipients, or in other words to a mass audience. Under mass media are included: the press, television, radio, film and the Internet. Mass media in the general communication serve as a channel for the transmission of messages.

According to Lukac mass media are:

1. Different set of activities (creation of media content);

$\begin{aligned} & 2 . \quad \text { Include specific } \\ & \text { (radio, }\end{aligned}$
$\begin{aligned} & \text { technological } \\ & \text { television, }\end{aligned}$
newspapers, books);

3. They are related to formally constituted institutions or media channels (systems, stations, publications);

4. They are acting in accordance with certain laws, rules and attitudes (professional ethics and practice, public, social expectations and habits);

5. They are product of people who occupy certain roles (owners, regulators, producers, distributors, advertisers, members of the audience);

6. They transmit information, parties, pictures and symbols to a mass audience (Lukac, 1976, p.54).

The definition which is known as Makluanova, determines the medium as any material supported entity that can transmit a message, so in accordance with this definition we can say that the medium represents a T-shirt with a slogan, a building with a political poster, a skin with tattoos and etc. According to the classically conventional definition, the medium is a communication system that is based on a technological device that broadcasts messages to the audience, and according to this definition a medium is the radio, which is based on the technological device radio apparatus, the television - which is based on a technological device the TV, the phone- which is based on the technological device handset, but also a medium can be $a$ book, a newspaper, a telegraph, a computer, an I-pod and so on. There is also a socalled technological definition according to which the medium represents the technology of writing or coding of messages, and according to this definition we can name the following media: electronic media, print media, digital media and others. When it comes to the Internet, we can use the term hyper-media, i.e. the medium over the medium, because it has incorporated a lot of technology and media in itself, such as: sound, picture, letter, radio, television, books, fax and many others. So given this fact, the Internet breaks the classical definition of the medium. ${ }^{1}$

Media allows communication between a large or small number of people. The media has a function to transmit messages that are created by someone to attract the attention of a wider audience, as well as to impose views. The people, who are actually the audience, should be familiar with the functions of the media, so they can easily understand the media messages and their intentions. In modern democratic societies the task of the media is to inform the populace about the work of the authorities and to promote different opinions, public debates and involvement of citizens in the society, and to promote democratic values and freedom of speech and expression. functions:

The media have the following

- Informative function, which means that the main function of the media is to inform the public with common and current topics from different areas of the social life of people.

- Function for the formation of opinions, which means that the media not only transmit information, they comment and interpret in ways in which the audience is offered different ways to understand the message and form their opinions.

- Function of social action, means that the media set priorities and can draw attention to something. The media have social functions, which can be divided into recreational, interactive and integrative. The continuous exposure to media influences the socialization of people and enables them

\footnotetext{
${ }^{1}$ Retrieved from: http://komunikacii.net/02/24/defining-blog/ Last visited: 20.03.2016.
} 
to be in pace with the current events. Through the media, the public can develop a sense of belonging to a particular environment or community, and to establish contact or communication. The most significant is the recreational or entertainment function that the media have which provides relaxation and escape to people from the everyday stress and dynamic. On the other hand, the media can have a negative effect or impact and contribute to the transfer of aggression and violence in the world. The media have social functions as well, which means that in democratic societies the media have a function to provide space so that the public can bring out different opinions and views, as well as interests in order to provoke public debate on a particular topic. The mass media provide communication among all socio-political entities, such as the parliament, the government, the political parties and the public. ${ }^{2}$

In Republic of Macedonia there is a Law on Media, which was adopted in 2013 and it regulates the basic principles and conditions which need to be met by the media publishers, gives definitions of basic concepts, and also regulates the issue of protection of the source of information. In terms of the Media Law of the Republic of Macedonia (Article 2) the media are means for public communication, i.e. for any kind of communication such as newspapers, magazines, radio programmes and television, teletext and other means of daily or periodical publishing of editorial shaped content in written form, sound or image in order to be informed and met the cultural, educational and other needs of the general public. Moreover, this law assigns that in media are not included newsletters, catalogs and other publications, regardless of the means of publication, which are designed exclusively for advertising, the education

\footnotetext{
2 Retrieved from: http://mediumi-ikomunikacii.wikia.com/wiki/\%D0\%9C\%D0\%95\%D0\%94\%D0\% 98\%D0\%A3\%D0\%9C\%D0\%98. \%D0\%A4\%D0\%A3\%D0\%9D \%D0\%9A\%D0\%A6\%D0\%98\%D0\%88\%D0\%90\%D0\%9D\%D0 $\% 90 \% \mathrm{D} 0 \% 9 \mathrm{C} \% \mathrm{D} 0 \% 95 \% \mathrm{D} 0 \% 94 \% \mathrm{D} 0 \% 98 \% \mathrm{D} 0 \% \mathrm{~A} 3 \% \mathrm{D} 0 \% 9 \mathrm{C}$ \%D0\%98\%D0\%A2\%D0\%95. Last visited: 20.03.2016.
}

system or business correspondence for the work of companies, institutions, associations, political parties, state and judicial bodies, public enterprises, legal entities with public authorities and religious organizations, and also according to the media law are not considered as well as the newspapers and the bulletins of educational institutions, "Official Gazette of the Republic of Macedonia", the publications of the local self-government posters, flyers, leaflets and banners.

The media content according to the Law on Media are all kinds of information (news, opinions, reports, statements and other information), as well as copyrighted works that are published or broadcasted through the media, while a media publisher is a natural person or legal entity who is doing the business of issuing the print media or radio and television programmes (broadcasters).

\section{International legal framework for the media}

The Law on Media represents a young legal discipline which is closely associated with the development of the media, especially the electronic media and the journalistic profession. The subjects of regulation of this legal discipline are mostly the relations in the media sphere. The objects of study of the Law on Media are the following:

- Freedom of expression and media freedom as a precondition for development of the democratic relations in the society;

- Media pluralism and media concentration;

- Regulation of the content of programmes;

- The regulation of advertising in electronic media;

- Hate speech;

- Types of broadcasters;

- The public broadcasting service;

- Access to public information;

- The right to privacy and protection of personal data;

- Regulation of defamation and protection of journalistic sources, notification of court 
proceedings and the right to reply and correct;

- Regulation of media coverage of election campaigns ( $\mathrm{PhD}$ Majhosev, 2015, p.4);

Like any other legal discipline, the Media Law has its sources that contain rules governing the scope of this discipline and that are sanctioned. In this paper, we will focus on the international sources of the Media Law, i.e. the international legal framework for the media. This international-legal framework consists of several legal acts, but the most important are the acts of the international organizations such as the United Nations and the Council of Europe. In addition, we will scrutinize separately the rules contained in some of the acts of the United Nations and the Council of Europe.

\subsection{United Nations Acts}

The Organization of the United Nations has an important role in the development of freedom of information as a human right. The most important international legal acts of the United Nations which contain media rules include:

- $\quad$ The universal Declaration of Human Rights,

- International Covenant on Civil and Political Rights and

Resolution 59 (1) on freedom of information.

\subsubsection{The Universal Declaration of Human Rights}

The Universal Declaration of Human Rights was adopted by the General Assembly of the United Nations on 10 December 1948 and it represents the first global expression of rights that belong to all human beings. The Declaration consists of 30 articles which have been elaborated in subsequent international treaties, regional human rights instruments, national constitutions and laws. ${ }^{3}$

Therefore, The UN General Assembly proclaimed The Universal Declaration of Human Rights as a common standard of achievement for all peoples and all nations, to the end that every individual and every organ of society, keeping this Declaration constantly in mind, shall strive by teaching and education to promote respect for these rights and freedoms and by progressive measures, national and international, to secure their universal and effective recognition and observance, both among the peoples of Member States themselves and among the peoples of territories under their jurisdiction. ${ }^{4}$

Article 18 of the Declaration stipulates that "everyone has the right to freedom of thought, conscience and religion." Article 19 stipulates that "everyone has the right to freedom of opinion and expression; this right includes freedom to hold opinions without interference and to seek, receive and impart information and ideas through any media and regardless of frontiers."

These freedoms and rights are implemented in most Constitutions of the member states of the United Nations, including the Republic of Macedonia.

In this section, briefly shall be clarified that freedom of expression constitutes one of the basic pillars of democracy. Namely, this freedom protects the right of individuals to shape and express their opinion and the right to establish associations that will encourage and disseminate their collective opinions on the social realities and developments. The freedom of expression shall grant each individual with the right to express oneself freely and shall not be prevented from no one. If the expression of opinion is limited, as well as the publication of facts and figures, then it can be said that democrasy does not exist.

\footnotetext{
${ }^{3}$ Retrieved from: https://en.wikipedia.org/wiki/Universal Declaration of Human Rights; Last visited: 20.03.2016.

${ }^{4}$ Retrieved from: http://civil.org.mk/wpcontent/uploads/2013/05/djeklarazia.pdf; Last visited: 20.03.2016.
} 


\subsubsection{International Covenant on Civil and Political Rights}

In The International Covenant on Civil and Political Rights, Article 18 stipulates that "everyone shall have the right to freedom of thought, conscience and religion", which stipulates that this right "may be subject only to such limitations as are prescribed by law and are necessary to protect public safety, order, health, or morals or the fundamental rights and freedoms of others." Article 19 of the Covenant stipulates that no one may be harassed because of their opinions, and that every person has the right to freedom of expression. This right, in fact, shall include freedom to seek, receive and impart information and ideas of all kinds, regardless of frontiers, either orally, in writing or in print, in the form of art, or through any other media of his choice. It may therefore be subject to certain restrictions, but these shall only be such as are provided by law and are necessary: (a) For respect of the rights or reputations of others; (b) For the protection of national security or of public order (ordre public), or of public health or morals.

Namely, the freedom of expression in any democratic society cannot be absolute, which means that it shall have boundaries and move within the achievement of other goals that have public interest (such as national security, public order and public morality). Indeed, freedom of media shall not mean their absolute freedom. Even in the most democratic societies may not be allowed the media to publish information that would endanger public interests. The philosophy of media freedom shall be the ability to strike balance between media freedom and freedom of expression of individuals.

\subsubsection{Resolution 59 (1) Freedom of Information}

The Resolution 59 (1) Freedom of Information from 1946 stipulates that the freedom of information shall be a fundamental human right and the basis for all freedoms that the United Nations are fighting for.

\subsection{Acts of the Council of Europe}

The most important legal sources of media law which have been adopted by the Council of Europe are:

- European Convention on Human Rights,

- European Charter for Regional or Minority Languages and

- Framework Convention for the Protection of National Minorities.

\subsubsection{European Convention on} Human Rights

The European Convention on Human Rights was signed on 4 November 1950 in Rome, Italy, but entered into force in 1953. This act is particularly important because has continuously developed through the interpretation of its provisions by the European Commission of Human Rights and by the European Court of Human Rights. This Convention shall be implemented by almost all States Parties, which it has been introduced in their legislation and it is part of their legal system. Article 10 of this European Convention on Human Rights stipulates that "everyone has the right to freedom of expression" (paragraph 1). For the purposes of this determination, the freedom of expression contains three components, namely:

- Freedom of opinion;

- Freedom to receive information and

- Freedom to impart information and ideas without interference by public authority.

It is necessary that all three aspects of freedom of expression to be exercised without interference from the government, whereas if any attempt is made to limit this freedom shall signify a direct threat to democracy and discrimination against people who have different opinion than others, and shall be a breach of the European Convention on Human rights. 
Under the European Convention on Human Rights freedom of expression may be subject to such formalities, conditions, restrictions or penalties as are prescribed by law and are necessary in a democratic society, in the interests of national security, territorial integrity or public safety, for the prevention of disorder or crime, for the protection of health or morals, for the protection of the reputation or rights of others, for preventing the disclosure of information received in confidence, or for maintaining the authority and impartiality of the judiciary. Article 10 shall not prevent States from requiring the licensing of broadcasting, television or cinema.

\subsubsection{European Charter for Regional or Minority Languages}

The European Charter for Regional or Minority Languages (ECRML) is a European treaty adopted in 1992 under the auspices of the Council of Europe to protect and promote historical regional and minority languages in Europe. Each country shall take certain measures in different areas including the media in order to promote the use of regional or minority languages. In article 11 of this Charter it is stated that the promotion of regional or minority languages in the media shall be vital for their preservation. Furthermore, it is specified that the parties shall undertake to ensure to users of regional or minority languages:

- Opening at least one radio station and one television channel in the regional or minority languages;

- To encourage or facilitate the opening of the press;

- For the application of this Charter shall be prepared periodic reports for the signatory countries by the Committee of Experts of the Council of Europe.

\subsubsection{Framework Convention for the Protection of National Minorities}

The Framework Convention for the Protection of National Minorities was adopted in 1995 and it pays special attention to the media. The provisions of this Convention determine that minorities should be ensured access to the media with the promotion of tolerance and cultural pluralism in the media.

In order this need to be accomplished should be taken more measures such as the following:

- $\quad$ Financial support of broadcasters that broadcast programs in minority languages;

- $\quad$ Funding for programs dealing with topics related to minorities or dialogue between different ethnic groups;

- To encourage editors and broadcasters to enable access of national minorities in their programmes.

In Article 9, paragraph 1 it is stated that "The Parties shall undertake to recognize that the right to freedom of expression of every person belonging to a national minority includes freedom to hold opinions and to receive and impart information and ideas in the minority language, without interference by public authorities and regardless of frontiers".

There is an advisory committee composed of eighteen experts that monitor the implementation of the Convention and publishes opinions on the Rights of minorities in the media area of the member states of the Council of Europe.

Globally, there are more international organizations or institutions that have a mission to improve the freedom of media and freedom of expression worldwide. Such organizations or institutions are:

- The International Press Institute, which is headquartered in Zurich;

- Reporters without Borders;

- Freedom House;

- Center for Freedom of Information, which is established within the University of Missouri, at the Faculty of Journalism. 


\section{Conclusion}

In conclusion it is vital to stress that the existence of strong and quality legal framework is the basis and guarantee for the actual existence and functioning of media freedom and their impact on the democratic relations in the society. Without quality media space and real treatment by the state, there is no media freedom. Media and freedom of expression in the long term make a strong influence on certain development processes and on the undeniable development of the institutional capacity.

Media freedom occupies an extremely important place in the overall living worldwide. We can conclude that media freedom is a process that is not finished because it is continuously developing and improving, even in the most democratic countries. All international laws that we have analyzed earlier in terms of their rules on media and freedom of expression undoubtedly indicate that there is a solid legal framework of a formal level in this area, so it is recommended their elaboration at a national level, in order to be allowed protection of these universal human rights.

The analyzed legal acts refer to the freedom of expression in general to any person or individual, and some of them even penetrate deeper, protecting the freedom of expression of minorities that exist in almost all countries. This is a very important foundation, which should be recognized and enshrined in all national rights in order hate speech to be avoided and to be allowed all minorities to express themselves freely in the media.

\section{References}

> Dimitrievic, Paunovic B., Gehrig M. (1997). Human rights. Center for human rights in Belgrade.

$>$ Lukac, S. (1976). Teorija I tehnika novinarstva. Fakultet politickih nauka, Beograd.

$>$ PhD Majhosev, A. (2015). Media rights (authorized lectures). University "Goce Delchev" Stip.
$>$ Trpevska, S. (2011). Freedom of expression, public interest and media regulation. School of Journalism and Public Relations, ExLibris Edition.

$>$ Retrieved from: http://komunikacii.net/02/24/defining-blog/; Last visited: 20.03.2016.

$>$ Retrieved from: http://www.vs.edu.mk/vs.edu.mk/index.php?opt $\underline{\text { ion }=\text { com content } \& \text { view }=\text { article } \& \text { id }=935 \& \text { Itemi }}$ $\mathrm{d}=190 \&$ lang=mk; Last visited: 20.03.2016.

$>$ Retrieved from: http://mdc.org.mk/mediumskotozakonodavstvo-vo-makedonija-nalikuva-nabrodovite-vo-vardar; Last visited: 20.03.2016.

$>$ Retrieved from: https://mk.wikipedia.org/wiki/\%D0\%A3\%D0\% BD\%D0\%B8\%D0\%B2\%D0\%B5\%D1\%80\%D 0\%B7\% $0 \%$ B $0 \% \mathrm{D} 0 \% \mathrm{BB} \% \mathrm{D} 0 \% \mathrm{BD} \% \mathrm{D} 0 \% \mathrm{~B} 0$ $\% \mathrm{D} 0 \% \mathrm{~B} 4 \% \mathrm{D} 0 \% \mathrm{~B} 5 \% \mathrm{D} 0 \% \mathrm{BA} \% \mathrm{D} 0 \% \mathrm{BB} \% \mathrm{D} 0$ $\% \mathrm{~B} 0 \% \mathrm{D} 1 \% 80 \% \mathrm{D} 0 \% \mathrm{~B} 0 \% \mathrm{D} 1 \% 86 \% \mathrm{D} 0 \% \mathrm{~B} 8 \% \mathrm{D}$ 1\%98\%D0\%B0 \%D0\%B7\%D0\%B0 \%D1\%87 $\% \mathrm{D} 0 \% \mathrm{BE} \% \mathrm{D} 0 \% \mathrm{~B} 2 \% \mathrm{D} 0 \% \mathrm{~B} 5 \% \mathrm{D} 0 \% \mathrm{BA} \% \mathrm{D} 0 \%$ BE\%D0\%B2\%D0\%B8\%D1\%82\%D0\%B5\%D 0\%BF\%D1\%80\%D0\%B0\%D0\%B2\%D0\%B0; Last visited: 20.03.2016.

$>$ Retrieved from: http://amos.org.mk/mak/covekovi/index.htm; Last visited: 20.03.2016.

$>$ Retrieved from: http://civil.org.mk/wpcontent/uploads/2013/05/djeklarazia.pdf; Last visited: 20.03.2016.

$>$ Retrieved from: http://www.healthrights.mk/pdf/Pravnici/Megju narodni\%20dokumenti\%20i\%20mehanizmi\%20 za\%20zastita\%20na\%20covekovite\%20prava/\% D0\%9EN/2\%20-

$\% 20 \% \mathrm{D} 0 \% 9 \mathrm{C} \% \mathrm{D} 0 \% \mathrm{~B} 5 \% \mathrm{D} 1 \% 93 \% \mathrm{D} 1 \% 83 \% \mathrm{D}$ 0\%BD\%D0\%B0\%D1\%80\%D0\%BE\%D0\%B4 $\% \mathrm{D} 0 \% \mathrm{~B} 5 \% \mathrm{D} 0 \% \mathrm{BD} \% 20 \% \mathrm{D} 0 \% \mathrm{BF} \% \mathrm{D} 0 \% \mathrm{~B} 0 \%$ D0\%BA\%D1\%82\%20\%D0\%B7\%D0\%B0\%20 \%D0\%B3\%D1\%80\%D0\%B0\%D1\%93\%D0\%B 0\%D0\%BD\%D1\%81\%D0\%BA\%D0\%B8\%D1 $\% 82 \% \mathrm{D} 0 \% \mathrm{~B} 5 \% 20 \% \mathrm{D} 0 \% \mathrm{~B} 8 \% 20 \% \mathrm{D} 0 \% \mathrm{BF} \% \mathrm{D}$ 0\%BE\%D0\%BB\%D0\%B8\%D1\%82\%D0\%B8 $\% \mathrm{D} 1 \% 87 \% \mathrm{D} 0 \% \mathrm{BA} \% \mathrm{D} 0 \% \mathrm{~B} 8 \% \mathrm{D} 1 \% 82 \% \mathrm{D} 0 \%$ B5\%20\%D0\%BF\%D1\%80\%D0\%B0\%D0\%B2 $\% \mathrm{D} 0 \% \mathrm{~B} 0 \% 20 \% \mathrm{D} 0 \% \mathrm{BD} \% \mathrm{D} 0 \% \mathrm{~B} 0 \% 20 \% \mathrm{D} 1 \% 8$ 7\%D0\%BE\%D0\%B2\%D0\%B5\%D0\%BA\%D0 \%BE\%D1\%82\%20\%D0\%B8\%20\%D0\%B3\%D 1\%80\%D0\%B0\%D1\%93\%D0\%B0\%D0\%BD\% D0\%B8\%D0\%BD\%D0\%BE\%D1\%82.pdf; Last visited: 20.03.2016.

> Retrieved from: http://bezomrazno.mk/wpcontent/uploads/2013/10/Megjunaroden-paktza-gragjanski-i-politicki-prava.pdf; Last visited: 20.03.2016. 